\title{
Stratified membership: health care access for urban refugees in Turkey
}

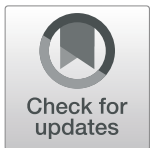

\author{
Wanda Spahl ${ }^{1,2^{*}}$ (D) and August Österle ${ }^{1}$ (D)
}

\author{
* Correspondence: wanda.spahl@ \\ univie.ac.at \\ ${ }^{1}$ Department of Socioeconomics, \\ WU Vienna University of Economics \\ and Business, Welthandelsplatz 1, \\ 1020 Vienna, Austria \\ ${ }^{2}$ Present Address: Department of \\ Political Science, University of \\ Vienna, Neues Institutsgebäude \\ (NIG), Universitätsstrasse 7, 1010 \\ Vienna, Austria
}

\begin{abstract}
Turkey hosts more refugees than any other country in the world. Incoming numbers have increased steadily since the outbreak of the Syrian war in 2011. This raises enormous challenges for the host country, not least with regard to the provision of healthcare. This article examines the developments in the light of stratified membership theories. More specifically, it asks how far the healthcare system in Turkey can be categorised as a system of stratified membership for different groups of urban refugees, focusing on refugees from Syria, Iraq and Afghanistan. Following a theoretical debate about stratification in the provision of social rights, 16 semistructured interviews with experts and active participants were carried out in Ankara to understand the situation of urban refugees in need of healthcare. The results confirm assumptions of stratified membership theories which understand citizenship in a broad sense as comprising the interconnected dynamics between social rights, legal status and identity requirements. Next to ethnic categories of origin defining the status in Turkey, factors such as language skills or the individual economic situation also play crucial roles for stratified membership both as an empirical fact and as a constructed practice.

Keywords: Access, Citizenship studies, Healthcare, Refugees, Social rights, Syrians, Turkey
\end{abstract}

\section{Introduction}

Currently, Turkey hosts more refugees than any other country in the world. Syrians are by far the largest group in the country, followed by people fleeing Iraq and Afghanistan. Situated next to Syria geographically and having pursued a de facto opendoor policy towards people fleeing from there, incoming numbers have increased steadily since the outbreak of the Syrian war in 2011. The high number of refugees ${ }^{1}$ arriving in Turkey opens up questions as to how the social rights of such an immense group of non-citizens can be met. As a fundamental social right, healthcare access lies at the heart of humanitarian care. It is reported that the camps organised by the Republic Of Turkey Ministry Of Interior Disaster And Emergency Management Presidency (AFAD) close to the border are generally well-managed (Alpak et al., 2015, Pfortmueller, Schwetlick, Mueller, Lehmann, \& Exadaktylos, 2016). Yet only around

\footnotetext{
'Refugee' will be used to refer to a person who fled his/her home country due to persecution. The term is used in a broad sense throughout the paper, not overlapping with the legal definition of 'refugee' in Turkey, nor taking up characterisations of legitimacy in terms of distinguishing between 'refugees' and 'migrants' (Crawley \& Skleparis, 2018).
}

(c) The Author(s). 2019 Open Access This article is distributed under the terms of the Creative Commons Attribution 4.0 International License (http://creativecommons.org/licenses/by/4.0/), which permits unrestricted use, distribution, and reproduction in any medium, provided you give appropriate credit to the original author(s) and the source, provide a link to the Creative Commons license, and indicate if changes were made. 
$10 \%$ of the Syrian refugees live in camps (Directorate General of Migration Management [DGMM], 2019; United Nations Development Group, 2018). Accordingly, the situation of the large number of non-camp refugees in the cities of Turkey, i.e. urban refugees, deserves attention.

Turkey has developed various mechanisms to cope with this situation. The Law on Foreigners and International Protection (LFIP, 2013) was adopted in Turkey in 2013 and represents the emergence of a political framework not only relating to migration to Turkey but also to the rights of refugees. This framework specifies which persons can apply for international protection in Turkey, guarantees non-refoulement and outlines refugees' rights to registration as well as the conditions of the application process for asylum (Kirisci, 2014; Öner \& Genc, 2015; Paçacı Elitok \& Straubhaar, 2012). In addition, a new institution, which plays a crucial role in implementing the LFIP, was created under the Ministry of Interior, namely, the DGMM. It is, however, important to note that Article 61 of the LFIP maintains the geographical limitation from the 1951 Geneva Convention, which restricts the status of 'refugee' to people from Europe (Ekmekci, 2016). Others can file protection claims, being subject to two parallel procedures. On the one hand, Syrian nationals and stateless persons coming from Syria who arrived in Turkey after April 28, 2011 by definition of the Temporary Protection Regulation (TPR) (2014) (provisional article 1), as based on Article 91 of LFIP, are granted temporary protection. On the other hand, non-Syrians can qualify for conditional or subsidiary protection (LFIP, 2013, articles 62 and 63). In this paper, the word 'refugee' is thus not used in the legal sense but generally for people fleeing their countries and residing in Turkey.

As well as constructing a political framework for migration, the LFIP (2013) and the TPR (2014) created a twofold system for refugees, separating procedures for Syrian and non-Syrian refugees. The former group is granted its rights by the TPR and the latter group depends on international protection, waiting years for resettlement by the Office of the United Nations High Commissioner for Refugees (UNHCR). As a result, both groups' stay is supposed to be temporary, without long-term prospects (Soykan, 2017), and the newly developed legal framework of migration in Turkey does not cover inclusive integration policies (Baban, Ilcan, \& Rygiel, 2017; Ekmekci, 2016). In February 2017, the UNHCR reported 2,910,281 registered Syrians in Turkey, compared to 2,715, 789 as of March 2016 (United Nations High Commissioner for Refugees [UNHCR], 2016b), and the number is still increasing (DGMM, 2019). Likewise, the number of UNHCR-registered international protection applicants has also risen from 258,405 to 295,401 (United Nations High Commissioner for Refugees [UNHCR], 2016a), consisting mainly of Afghans, Iraqis, Iranians and Somalis.

Given the large number of Syrians, the situation of the international protection applicants in Turkey has rarely been researched. Hence, this article complements research on Syrians only (e.g., Baban et al., 2017; Bilecen \& Yurtseven, 2018; Mardin, 2017) by focusing to an equal degree on refugees fleeing Iraq and Afghanistan. Afghan refugees in Turkey are a particularly vulnerable group and rarely researched (Alemi et al., 2017; Ikizoglu Erensu, 2016).

The article asks to what extent the healthcare system in Turkey can be categorised as a system of stratified membership for different groups of refugees. Next to empirical insights from semi-structured interviews conducted in Ankara between February and 
June 2016, this article contributes to the theoretical debate about the provision of social rights. Stratified membership helps to better understand both the practical consequences of the legal divisions in the realm of healthcare outlined above, and preliminary empirical insights during fieldwork about varying degrees of access. Social policies towards refugees are understood as mechanisms of inclusion and exclusion (Ataç \& Rosenberger, 2013; Baldi \& Goodman, 2015; Joppke, 2007; Morris, 2002), not only reflecting the coverage of basic needs but also the political realisation of the contested issues of citizenship and integration.

The next section briefly outlines the Turkish healthcare system, with its recent reform to a universal system and a view to creating access barriers for refugees. Then the theoretical foundation of the article is explained - citizenship as stratified membership -, building on the extension of citizenship rights to non-citizens and the specific importance of social rights for immigrant groups. After a brief overview of the methods applied, key findings are presented and contextualised using concepts of stratified membership. Finally, the article concludes with a brief summary and suggests directions for future research.

\section{The Turkish healthcare system and barriers for refugees}

The Turkish healthcare scheme has undergone major transformations since the introduction of the Health Transformation Program in 2003. The overall goal was universal health coverage. Respective measures dealt with organisation, funding, resource allocation and service delivery. The success of the reform is widely recognised. Some scholars also praise the new health system as having fully achieved its goal of an equal system of universal coverage (Atun, 2015; Atun et al., 2013). Others focus more critically on parallel forms of marketisation and associated privatisation (Aktan, Pala, \& Ilhan, 2014; Bugra \& Candas, 2011), risking the exclusion of vulnerable groups. As examples, Agartan (2012, p. 467) names "geographical barriers to accessing health facilities, inequalities in the distribution of health personnel and high-quality facilities and informal payments that limit access to services." Low-income groups and the majority of refugees are especially vulnerable to these market-based restrictions in the universal system. It is reported that co-payments for treatments beyond primary care are regularly expected from refugees in Turkey (United Nations Development Group, 2015).

Access to public healthcare services usually requires a valid Turkish ID card (LFIP, 2013) permits an equal right of access to registered migrants. Respective services to refugees are delivered by state and non-state organizations, but delivery thereof depends on permissions by governmental bodies (Ozcurumez \& Yıldırım, 2017). Despite these new regulations, recent studies find that barriers to healthcare access persist for Syrians in Turkey (Bilecen \& Yurtseven, 2018; Mardin, 2017), while they are rarely explored for other refugees. Such access barriers for refugees and immigrants have been well researched in the Global North (Sargent \& Larchanché, 2011). But the situation of countries currently hosting high numbers of refugees, such as Turkey, Lebanon and Jordan, remains under-researched (Parkinson \& Behrouzan, 2015). In Turkey, existing literature investigating health status, healthcare access and treatment of refugees has focused mainly on the situation in the camps (Alpak et al., 2015; Pfortmueller et al., 2016). In contrast, there are only few studies examining the urban refugee population (Abbara et al., 2016). Challenges identified in the delivery of health to Syrian refugees 
in Turkey include language barriers, problems in navigating the system and in registration (Bilecen \& Yurtseven, 2018); a lack of translators, adequate follow-up treatments, delayed registration processes due to a lack of knowledge (Ekmekci, 2016); and a high number of claimants, a lack of knowledge about the legal rights situation among the healthcare staff, and inadequate continuous treatment (Kirisci, 2014).

Ankara, the case being examined in this paper, - with more than five million inhabitants - hosts 88 hospitals with 34.4 hospital beds and 4.9 intensive care unit beds per 10,000 people. More than 2000 general practitioners and more than 10,000 specialist physicians operate in the city (Republic of Turkey Ministry of Health, 2016). Despite this supply of medical institutions, our empirical data indicates that refugees mainly get treatment in only a small number of public hospitals.

\section{Concepts of stratified membership}

Migration challenges the classical perception of belonging in the welfare state, in which social rights such as healthcare access have been mainly reserved for citizens (Marshall, 1950). It is argued that granting social rights to immigrants might lead to social tensions as it requires a different legitimisation than the classical welfare state's, which is rooted in a unified citizenry (Joppke, 2007). The fact that some newcomers, such as asylum seekers, are socially in need rather than net contributors further challenges perceptions of a unified society which is ethnically equal and draws clear boundaries between insider citizens and outsider non-citizens. This, and claims that emphasise immigrants' responsibilities instead of their welfare state entitlements, make extensions of social rights to non-citizens counter-intuitive.

However, since the 1990s, an increasing body of literature has documented the granting of social rights to immigrants while not offering them naturalisation in the form of becoming citizens. Hence, social rights increasingly accompany legal status as a second dimension of citizenship. This has led to a reconceptualisation of citizenship as comprising both the legal and the social rights dimension. Furthermore, it is argued that a third dimension of citizenship, the identity dimension, is increasing in importance, which again results in reduced social rights for immigrants (Joppke, 2007). One example in this regard are political measures that tie eligibility for social benefits to language requirements.

Multidimensional understandings of citizenship break up dichotomies between citizen and non-citizen. Through the lens of stratified membership theories (Baldi \& Goodman, 2015; Joppke, 2007; Morris, 2002; Olafsdottir \& Bakhtiari, 2015; Sainsbury, 2012; Willen, 2012), this article views citizenship as manifold statuses along a continuum on a variety of axes of legal status, identity and rights. It proposes a dynamic model which extends the binary categories of citizen and non-citizen, includes pathdependent behaviour and orients itself towards empirical developments in nation-state structures in terms of both formal rights and realities. With the focus on social citizenship, a distinction between formal and substantial rights is particularly helpful (Sainsbury, 2012). Forms of access may not only be entry categories in the sense of legal distinctions, such as between asylum seekers and labour migrants, but also informally established categories of stratified membership at a variety of levels. For instance, special needs resulting from language or religion can also be a substantial hurdle (Castles \& Schierup, 2010). These are part of a person's identity, irrespective of their legal 
status and their entitlements in the form of rights. This societal construction of different groups of immigrants by the receiving countries (Sargent \& Larchanché, 2011) shapes the bureaucratic structure applied by host countries in designing access to healthcare. Accordingly, Olafsdottir and Bakhtiari (2015) understand health policies both as symbolic and as direct mechanisms of social inclusion and exclusion. As a result, healthcare policies are part of constructing categories of belonging in the nation state.

Citizenship is arguably more than legal status and may even comprise acts of citizenship outside any predefined or regulated dimension (Isin \& Nielsen, 2008), such as individual practices by doctors who challenge the social order by treating undocumented migrants. Still, national welfare states continue to play a crucial role in the provision of social rights to immigrants, as they decide who is an eligible welfare recipient (Bommes \& Geddes, 2000). It is thus the aim of this article to examine differentiation along the axes of legal status, identity and rights in Turkey. Based on empirical data, it contributes to a better understanding of varying healthcare accessibility for different groups of migrants, along multiple lines, including but going beyond ethnicity. ${ }^{2}$

\section{Methods}

The analysis is based on sixteen semi-structured interviews (Brinkmann, 2013; Ritchie, Spencer, \& O'Connor, 2003) carried out in Ankara between February and June 2016 to understand the situation of urban refugees in the Turkish capital. We identified interlocutors from a broad range of positions in order to gain comprehensive insights from a variety of perspectives. Table 1 illustrates the position of the interviewees (two leading personalities from within the refugee communities, four health personnel, five nonstate refugee supporters, three state affiliated actors, two academics), their gender (nine male, seven female), the language (eight in English, eight with an interpreter), and the type of documentation (ten recorded and transcribed, six with notes). The interviews followed an interview guide with open-ended questions, which we slightly modified when interviewing refugee community members. The interviews with the latter took place within their district. All others were carried out at the interviewee's institution. We distinguished between interlocutors who mention differences across refugee groups without being prompted and the ones who do not. Framework analysis was used as the method of analysis (Gale, Heath, Cameron, Rashid, \& Redwood, 2013, Pope, 2000, Ritchie et al., 2003), allowing comparability among cases and topics from interlocutors with varying positions.

Establishing contact through formal channels turned out to be extremely difficult. Email requests, sent to NGOs in both Turkish and English, remained unanswered as did formal petitions for a scientific interview with governmental bodies. As an alternative, we used the snowball method among our wider personal and professional network. Furthermore, certain tendencies indicate that, counter to intuition, it was an advantage to be an 'outsider interviewer', in the sense of being a non-Turkish, non-Arabic, German-speaking researcher interviewing refugees and citizens in Turkey. Even though different conditions were necessary to gain trust in each group, ethnicity or nationality did not prompt negative interactions in either. The researcher's political affiliation was

${ }^{2}$ This article uses 'ethnicity' to refer to the different places of origin of the refugees in focus. While 'nationality' is decisive for the legal divisions, ethnic categories play vital roles, as exemplified with the Iraqi Turkmen community. 
Table 1 Interviews conducted in Ankara in 2016

\begin{tabular}{|c|c|c|c|c|c|}
\hline $\begin{array}{l}\text { Interview } \\
\text { No. }\end{array}$ & Interviewee & Position & Gender & Language & Documentation \\
\hline 1 & $\begin{array}{l}\text { Administrative state hospital } \\
\text { staff member }\end{array}$ & health personnel & $\mathrm{m}$ & $\begin{array}{l}\text { Turkish } \\
\text { (interpreter) }\end{array}$ & notes \\
\hline 2 & Afghan & $\begin{array}{l}\text { refugee community } \\
\text { member }\end{array}$ & $\mathrm{m}$ & $\begin{array}{l}\text { Farsi } \\
\text { (interpreter) }\end{array}$ & transcript \\
\hline 3 & ASAM $^{3)}$ employee & state affiliated & $f$ & English & transcript \\
\hline 4 & Human rights expert & academics & $f$ & English & transcript \\
\hline 5 & Human rights student & academics & $f$ & English & notes \\
\hline 6 & Iraqi Turkmen & $\begin{array}{l}\text { refugee community } \\
\text { member }\end{array}$ & $\mathrm{m}$ & $\begin{array}{l}\text { Arabic } \\
\text { (interpreter) }\end{array}$ & transcript \\
\hline 7 & Medicine student & $\begin{array}{l}\text { non-state refugee } \\
\text { support }\end{array}$ & $\mathrm{m}$ & English & transcript \\
\hline 8 & $\begin{array}{l}\text { Neighbourhood foundation } \\
\text { associate }\end{array}$ & $\begin{array}{l}\text { non-state refugee } \\
\text { support }\end{array}$ & $\mathrm{m}$ & $\begin{array}{l}\text { Turkish } \\
\text { (interpreter) }\end{array}$ & notes \\
\hline 9 & $\begin{array}{l}\text { Official from a district } \\
\text { social department }\end{array}$ & state affiliated & $\mathrm{m}$ & $\begin{array}{l}\text { Turkish } \\
\text { (interpreter) }\end{array}$ & transcript \\
\hline 10 & Social worker & state affiliated & $\mathrm{m}$ & $\begin{array}{l}\text { Turkish } \\
\text { (interpreter) }\end{array}$ & transcript \\
\hline 11 & Religious charity representative & $\begin{array}{l}\text { non-state refugee } \\
\text { support }\end{array}$ & $\mathrm{m}$ & $\begin{array}{l}\text { Turkish } \\
\text { (interpreter) }\end{array}$ & transcript \\
\hline 12 & State hospital doctor & health personnel & $f$ & English & notes \\
\hline 13 & Turkish Medical Association doctor & health personnel & $f$ & English & transcript \\
\hline 14 & $\begin{array}{l}\text { University support } \\
\text { group member }\end{array}$ & $\begin{array}{l}\text { non-state refugee } \\
\text { support }\end{array}$ & $\mathrm{m}$ & English & notes \\
\hline 15 & WHO employee & $\begin{array}{l}\text { non-state refugee } \\
\text { support }\end{array}$ & $f$ & English & transcript \\
\hline 16 & Women health centre workers & health personnel & $f$ & $\begin{array}{l}\text { Turkish } \\
\text { (interpreter) }\end{array}$ & notes \\
\hline
\end{tabular}

The Table illustrates the interlocutors and settings of the interviews. They are the empirical basis of the article, and were conducted by the researchers in Ankara between February and June 2016

also not a source of curiosity. This case study germinates the notion that being an outsider actually stimulates an environment of trust that leads to richness in the data. Some informal interviews with Turkish scholars reinforced this evolving proposition. This article thus supports studies which reject one-dimensional ideas of 'insider researchers' whose qualifications are mainly co-ethnicity or co-nationality and favour conceptions of multiple statuses along which trust can emerge (Ergun \& Erdemir 2010; Ryan, Kofman, \& Aaron, 2011; Shinozaki 2012). Yet establishing the necessary informal contacts took time. We had to reschedule interviews at short notice and use unexpected windows of opportunity. Overall, this confirmed that, as the field of migration studies is expanding rapidly and qualitative research becomes internationalised with increasing global research programmes and mobile researchers, often with few methodological considerations, sensitivity about a foreign researcher's role is essential.

\section{Key findings: stratified membership as empirical fact or as constructed practice?}

Overall, the research process revealed two distinct ways of understanding stratified membership practices. Firstly, they can be seen as empirical 'facts'. In this understanding, information from the interviews about the legal situation and institutional practices 
build an empirical picture of varying lines of stratification currently evolving within healthcare access for urban refugees. One example is the opening of Migrant Health Centers for Syrians in 2017 which separates this group from both other refugees and Turkish citizens. The centers, mainly established in South-East Turkey, employ Syrian healthcare personnel for treating Syrians only (Bilecen \& Yurtseven, 2018). This approach had not yet been established at the time of the interview with the WHO employee. Yet their defense of it, and their vigorous refusal to call it a parallel structure, reveals the tensions that the Turkish healthcare system faces with such a high number of immigrant arrivals. The interlocutor is aware that a separated system leads to longrun segregation with spillover effects to other social realms, yet puts emphasis on the short-term relief:

So, but these are not actual we don't call them parallel systems or parallel services because it is not good. Even if they are parallel we don't like to use this term, because it is like I heard that from a German doctor actually recent in a meeting he said, he didn't like this idea, he said they did it for Turkish people in Germany some years ago, so it led how you say it, to establish small communities among German people, which is not good, they have to be integrated in the system actually [inaudible] so we don't say they are parallel but at the moment. I mean you cannot wait for health. You cannot wait until they are integrated in the community. (WHO employee)

Secondly, stratified membership can also be understood as a constructed practice. Each interlocutor portrays the situation in a distinct manner. The narratives of healthcare access by the interlocutors itself construct stratified membership. Many interviewees describe the situation for refugees but are actually referring to Syrians only. For example, the aim formulated by the medicine student, the university support group member and the neighbourhood foundation associate, is to help refugees as a broad category. In fact, they support the Syrian community specifically. Another example encountered is the Turkish Medical Association doctor, who, on being asked about the registration process for refugees, explains the procedure for Syrians only. Generally, when speaking about issues in accessing healthcare, the interlocutors mostly expand on Syrians. Asking about 'refugees' in the interviews and letting the interlocutors talk freely made it possible to understand constructions of 'refugeeness'. Accordingly, it could be observed that when interviewees introduced non-Syrian refugees, it often happened in reference to or as a contrast with Syrian refugees. Access to healthcare for Syrians is frequently compared with the one for Turkish patients. Others separated women and children, and Afghans and Iraqi Turkmen as distinct refugee groups within the international protection applicant group. In this way stratified membership can be understood as a constructed practice.

\section{The legal procedure}

The data about the legal procedure confirms a parallel procedure, i.e. a two-track system. Syrians are by definition temporary protection applicants. For them a variety of actors are involved with the registration system, and there is no central coordination. Non-Syrian refugees are international protection applicants. 
They are like trying to create this separate track for Syrians. For education, for work and for health. That's why I want to write a paper about that. They are separating everything. They are discriminating against the other group. (human rights expert)

The human rights expert explains that the various legal mechanisms create a social system for Syrians only, which discriminates non-Syrian refugees who do not have access to those targeted services. Despite these separate tracks, neither temporary protection applicants nor international protection applicants have long-term prospects from the Turkish authorities (Ekmekci, 2016; Soykan, 2017). However, most of the refugees have resided in the country for many years.

Registration is crucial for healthcare access, as has been confirmed by other studies focusing on healthcare access for Syrians in Turkey (Bilecen \& Yurtseven, 2018). Still, in practice there is no guarantee of a fast or standardised process. While Syrians can register in all cities in Turkey, the human rights expert states that international protection applicants are expected to stay in so-called satellite cities, which are often in economically weak and rural areas. There they register for UNHCR appointments via Association for Solidarity with Asylum Seekers and Migrants ${ }^{3}$ (ASAM) offices. ${ }^{4}$ However, she indicates that in practice many of them reside in Istanbul, Izmir, Ankara etc. Within the latter group, Iraqis typically wait for a shorter amount of time before resettlement than Afghans. Residence permits which grant healthcare access are relatively easy for them to receive. For Afghans, however, there are no general resettlement policies. Hence, the human rights experts indicates that they often leave Turkey irregularly after years of waiting. They have also had more problems since the increased arrival of Syrians to Turkey. While registration for international protection applicants follows standardised procedures, we find that practices discriminate against Afghans. Indeed, Afghans protested in Ankara in front of the UNHCR Turkey head office in 2014 due to suspended registration procedures and deferred recognition procedures (Ikizoglu Erensu, 2016).

Our data furthermore indicates that the Afghans' difficult situation, where the lack of a residence permit means they receive no healthcare treatment, forces this community to find solutions for themselves, often by directly asking medical personnel for informal help. Furthermore, the assumption of the interviewed WHO employee that non-Syrians, mostly Afghans, apply for a Syrian ID card in order to access services deserves closer attention. Our findings thus support recent research findings that Afghans in Turkey are also in a vulnerable position due to problematic registration conditions (Alemi et al., 2017; Ikizoglu Erensu, 2016). They are left with few rights, and in some instances are perceived as security threats rather than as deserving individuals.

\footnotetext{
${ }^{3}$ ASAM (Turkish: Sığınmacılar ve Göçmenlerle Dayanışma Derneği) is an NGO founded in 1995 in Ankara (Ozcurumez \& Yıldırım, 2017). It is an implementation partner of both UNHCR and the Turkish government as it takes an active role in building up the healthcare net for immigrants. UNHCR registration is mediated by ASAM for non-Syrian refugees. The responsibilities of UN agencies, national and international NGOs and state institutions are intertwined. The ASAM employee emphasises their role as an independent NGO.

${ }^{4}$ Procedures changed in 2018. The UNHCR office in Ankara now restricts its activities to counseling and protection. Provincial DGMM offices in satellite cities register international protection applicants and provide them with an ID card which offers access to healthcare services (United Nations High Commissioner for Refugees [UNHCR], 2019).
} 
It has to be noted that at the time of the interviews, the immigration system had not yet developed any formal systems for providing healthcare to refugees, and informal mechanisms were therefore in place. This reflects the general confusion surrounding the situation, expressed directly by the interlocutors and found in diverging statements from the interviews.

While some features are shared across refugees with different countries of origin, the legal situation and barriers to accessing health services can vary considerably. In accordance with the literature (Bilecen \& Yurtseven, 2018), all interlocutors indicated that life-saving emergency treatment is universal, even for irregular migrants. For non-emergency treatment, though, the situation is more complex. After having received valid documents, Turkish citizens and foreigners both have access to the Turkish healthcare system. Yet there are systemic discrepancies. The following sections focus on issues leading to these discrepancies in a system which is relatively equal in formal terms, namely, problematic conditions in the overall healthcare system, unequal financial circumstances, and factors such as self-organisation, gender, and religion.

\section{Problematic conditions in the healthcare system}

Problematic conditions in the healthcare system overall emerged as crucial when discussing healthcare access. Some interlocutors indicated that barriers to healthcare are inherent to the system, regardless of status, be it citizen, international protection applicant or temporary protection holder. The general situation in Turkey is challenging. Refugees are viewed as a tipping point for an already overloaded system which was not prepared for additional patients. However, there are problems within the healthcare system that also make it weak for native-born citizens. The quality of public treatment is evaluated as bad by two doctors. This observation can be interpreted as indicating that people actually receive the same treatment irrespective of status, within a system with poor quality overall. Here a line of stratification emerges, which assigns a relatively bad public system to the poor and a better private system to the rich. Nevertheless, low-income Turkish citizens have facilitators in circumventing the pitfalls of the public system such as arrangements with private hospitals. Other general conditions make it especially hard for people with a refugee status, whether they are Syrians or international protection applicants, since both are groups with high vulnerability, who lack long-term prospects and are dependent on restrictive work permits.

The critical situation in public hospitals reveals implementation dynamics when granting social rights to non-citizens. When the state hospital doctor describes the formal process of accessing healthcare, he says that Turkish patients and refugee patients are treated in the same way. However, he deviates from this when describing his dayto-day experience, stating that some of his colleagues do not want to treat refugee patients. The state hospital doctor then takes in these patients, working up to his own limits and increasing his patient-doctor ratio without an increase in payment. He explains that he simply has to work faster and for longer hours, describing an overloaded system in which some doctors dedicate the means they have to the new group of patients, and others are reluctant to do so. It is intriguing to see in individual doctors' behaviours how far they support the opening of certain citizenship components to noncitizens in their daily practice. 
Consequently, while refugees are formally granted the social right to healthcare, this can be difficult to implement in practice. There is a tension between legal provisions and an overstretched healthcare system. Much of the health personnel is working at their limit. With this background, the interviewed state hospital doctor does not criticise colleagues for refusing to treat refugee patients. Instead, he criticises the flaws in the Turkish healthcare system. He is angry at the government for not increasing the capacity of the healthcare system, despite promises made. Mostly, hospitals are not paid for the additional work of caring for refugees. Consequently, the social right dimension hinges upon the hospital staff's practices. The budgeters, such as members of a state hospital's administration staff, decide to grant the social right irrespective of outside support or not, and the doctors decide for themselves if they will engage in more work to expand these rights to refugees.

Beyond general conditions of the healthcare system in Turkey, the Iraqi Turkmen remarks that the provision of services to refugees is less crucial than the admission of people fleeing. This adds a more basic view on health, linked to survival.

The Turkish government even though they didn't give like a lot of money I mean sufficient to cover every need, but at least they opened the borders and they were able to finish with that and war and that's the most important things, to stay alive. (Iraqi Turkmen)

\section{Unequal financial responsibilities}

The healthcare reform has resulted in an overall co-payment system which incurs additional costs for treatments beyond primary care. These additional costs are especially problematic for patients in poor economic conditions. The fact that economic standing creates divisions in care crosscuts the citizen/refugee status as well as among different refugee groups. In general, interlocutors report a bureaucratic and complex system of payment. The crucial role of a valid ID card for getting treatment within the Turkish system is the underlying premise. Costs are a vital issue for all refugees. Chronic illnesses pose considerable financial challenges. Still, for Syrians and non-Syrians, some major treatments are not covered by the general health insurance, which pays for international protection applicants, nor by AFAD, which covers the costs of Syrians. There are also public arrangements with private hospitals that apply for Turkish citizens only, even though Turkish citizens and refugees with a valid ID card are officially supposed to be covered by the same health insurance scheme.

Next to a general system with additional costs beyond state provisions and informal extra costs for refugees, differences between refugee groups have been reported. Financially, the Afghan community is under the most pressure, mostly due to the fact that many of them have problems registering for official status; the Iraqi Turkmen are mostly covered, and the Syrians even more so. For Syrians, interviewees discussed additional healthcare costs but also exemptions, of e.g. service fees which Turkish people have to pay. They might also enjoy advantages in some parts of Turkey where many Syrians live and healthcare infrastructures have developed which specifically target the Syrian population. For international protection applicants, only additional costs are mentioned. The interlocutors clearly state that they, in contrast to Syrians, 
have to pay the service fees for both treatment and for medicine. However, the ASAM employee notes that Iraqis can go to more hospitals than Syrians; the system for them has emerged over a longer period of time. This emphasises again the dynamic nature of the system. According to the human rights expert, there are differences across Turkey when it comes to covering extra costs for international protection applicants. In contrast, centralised payments for Syrians by AFAD are relatively straightforward.

On the institutional side, financial pressures endanger equal access. The state hospital staff claims that the state often does not cover refugee bills, counter to earlier arrangements. There is a discrepancy between formal arrangements and the operational outcome. As already mentioned, the goodwill of the medical staff is crucial at the implementation level. Yet, as shown by the understaffed and overcrowded hospitals with tight budget restrictions, this is a system which might easily collapse. The interviewees often critique the management, while acknowledging the challenging situation.

We do it. You saw the man working there (referring to an Arabic-speaking employee of the Foreign Patient Admission office). I think they are paid very little, but they talk to them like friends. (state hospital doctor)

\section{Self-organisation, gender, and religion}

In finding solutions to the challenges described, self-organisation within the refugee communities is widespread. All refugees show strong ties within their respective community, with dynamic structures of mutual help. Thereby, the evidence gathered suggests that Iraqi Turkmens are better networked at higher administrative levels than Afghans. Rather than providing healthcare access to individual cases, the Iraqi Turkmen describes efforts to change the overall structure. Varying levels of proactivity and structural possibilities to change their own situation remain an exciting field to research differences across the refugee communities. Furthermore, refugee doctors practicing illegally is widespread in the Syrian community. They are ambiguous figures. On the one hand, they represent the empowerment of refugees as actors who are otherwise constrained by work permits and a foreign healthcare system. On the other hand, they separate Syrians from the official healthcare system, and leave them in a parallel and inferior structure.

The situation of women has to be highlighted as an especially vulnerable group. Cultural differences between the refugee populations from different countries play a role; as Afghan women are extremely difficult to reach, the Turkish Medical Association doctor evaluates their access to healthcare as particularly problematic. Abortions are also an issue which might put Turkish and refugee women into difficult and possibly dangerous situations.

One thing that we face so often is that when they become pregnant and when they want to have an abortion and it's so so hard. Of course not just for the Syrian women. All women in Turkey unfortunately but especially for them, because the system wants their husband's permission to have the abortion, but it's generally impossible. (Turkish Medical Association doctor)

There are instances which tackle the difficulties for women. The four Women and Girls Safe Spaces in Ankara target refugee women. They were established jointly by a public 
university, the United Nations Population Fund and the Ministry of Health. While they provide medical treatment for women by sensitive staff, implementation fails to recognise important needs. Our empirical data suggests that the placement of the centres does not correspond to the refugees' houses. Also, one of the centres shares the building with a local police station, putting its function as safe space for women into question.

Varying healthcare access and associated problems might also relate to religion. However, our data does not suggest that religion plays a vital role, with most interlocutors not mentioning it at all. Exceptionally, the ASAM employee speculates that Iraqi Turkmen, being Sunni, might have easier healthcare access than Afghans. The religious charity representative denies the role of religion in his account: he says that all refugees in Turkey are treated the same. The social worker highlights cultural differences between the Turkish and the Syrians. For him, religion is not an issue in the current situation. He emphasises that Iraqis, who according to him are mostly Turkmen, get along well in Turkey in terms of culture.

An attempt to structure the differences between different refugee groups leads to the following clusters: Syrians receive treatment under the best conditions, and are even partly exempt from co-payments that Turkish citizens have to make. Turkmen face some additional costs compared to Syrians, but their system has been established for longer. Finally, many Afghans just rely on the goodwill of doctors as many of them are not registered, mostly due to the discriminatory practices described above. They also face barriers due to their religious beliefs, and social resources such as a lack of networks at higher administrative levels. While some interviewees see tensions, overall differences are not spelled out clearly. Most interlocutors are rather engaged with other topics and only formulate the differences clearly in direct comparisons when probed.

\section{Contextualising the findings with concepts of stratified membership}

Stratified membership theories as outlined above understand the dimensions of status, rights and identity, which together constitute citizenship, as a mutual net of conditions. They influence one another in a continuous manner. Examples for these dynamics are the reported practices of health personnel which shape citizenship rights, both by narrowing and by widening them. The informants reported informal medical help which was given on an individual basis when patients did not have a valid ID card as well as out-of-pocket payments by the hospital administration when the state authorities did not remunerate treatment costs for refugees. These instances influence the dimensions of status and rights. Both practices occur in the dimension of rights; through their daily work, the health personnel turn legal rights into social rights, thereby producing practices of inclusion and exclusion, irrespective of status attributes and formal rights. Another direction of influence is characterised by the finding that some doctors refused to treat refugees, despite their successful registration and possession of a valid ID card, producing practices of exclusion. Importantly, these three instances of informality form civic membership as well. Healthcare access in this regard is a vital part of citizenship, in which inclusive and exclusive mechanisms are mediated.

Interlocutors emphasise that the newly established immigration regime in Turkey is still evolving. Similarly, in Italy, Morris (2002) points to discrepancies between formal access criteria and the experience of migrants. This resonates in the Turkish case as there are also formal entry criteria - highlighted in this paper through the statuses of 
Syrians under the TPR (2014), non-Syrians eligible for international protection, and irregular migrants without official documents - but also informally established entry criteria. Our findings are in line with other recent scholarship that stresses the gap between legal provisions and actual healthcare access for Syrians (Bilecen \& Yurtseven, 2018). What we add is a more differentiated analysis, which is not confined to ethnicity and takes into account varying degrees of access.

At the level of rights, our analysis of the implementation for refugee healthcare rights in Turkey showed that state institutions are still the main bodies that provide this social right. The role of NGOs and international bodies is restricted to financial support and training offers to help Turkish health personnel cope with the situation. Non-state support is also often in close collaboration with the state and carried out next to purely public health facilities in state hospitals and institutions that take on hybrid forms such as the Women and Girls Safe Space. These findings confirm that the nation state and its power in granting rights to the individual cannot be overlooked. In the implementation dynamics described, however, it becomes clear that there are more relevant factors. Subsequently, essentializing the state and adhering to methodological nationalism is also misguided (Wimmer \& Glick Schiller, 2002).

(R)ather than dismissing or essentialising the nation-state, it is useful to consider citizenship and health policy at a variety of levels, from interpersonal processes of social exclusion to global frameworks of social rights. (Olafsdottir \& Bakhtiari, 2015, p. 564f)

The status dimension in the overall conditions, with the registration process and the two-track system, is particularly crucial. It is legal status that is decisive in the Turkish case, and not citizenship status in the narrow sense of the word. Social rights for refugees depend on the legal status of accepted non-citizens within the international protection procedure or the temporary regime for Syrians. A narrow conception of citizenship in the sense of nationality as status is not decisive for receiving welfare benefits, but the legality of residence is crucial for refugees in Turkey. A valid identity card for Turkey is the prerequisite for receiving social benefits. As the most vulnerable group with the least secured access to healthcare, Afghans have the highest number of members without a legal status. Generally, it is less costly for national bureaucracies to offer universal social rights to citizens and immigrants than to deliver special services (inter alia Guiraudon, 2000). Since its reform, the Turkish healthcare system has adhered to the same principle of equality, including the incorporation of refugees with valid IDs. In theory, being legal is a given in the status dimension, and refugees and Turkish citizens are thus treated under the same healthcare scheme. Yet, contrary to this universal claim, practices by administrative and health personnel informally establish differences. Furthermore, individual claims of deservingness (Willen, 2012), which are based on moral imperatives, can be the basis for support. Those discrepancies between rights and practices are also prerequisites for the described self-organisation of refugees, which should be further investigated when applying the concept of acts of citizenship (Isin \& Nielsen, 2008).

Some of the problematic general conditions indicate that barriers to healthcare are systemic problems, irrespective of the status dimension, be it citizen, international protection applicant or temporary protection holder. The low staff-patient ratio and the 
system of co-payments, together with a qualitatively better private health system, divide the Turkish system along economic lines. This division of poor and rich crosscuts even citizen and non-citizen status. Still, public arrangements with private hospitals for Turks only uphold the status stratification between citizens and non-citizens, counter to the idea of the supposed universal coverage in an equal access national healthcare scheme.

The Turkish case does not depend on a formal identity dimension as do some European countries, with civic integration requirements such as state-provided language and culture courses or requirements of self-sufficiency (Joppke, 2007). Considering a lack of integrational measures and long-term prospects for refugees in Turkey, irrespective of their status, the dimension of identity plays an informal role in the analysed setting. The findings reveal how it is a vital part of civic membership. Language is crucial for urban refugees' healthcare access; this was no problem for the Turkish-speaking Iraqi Turkmen. Furthermore, cultural differences play a role, as seen with the Afghan communities' insularity. Consequently, intersectional problems can be observed. Female members of the Afghan community are especially difficult to reach. Another informal distinction, religion, was not an essential topic for healthcare access. Nevertheless, the Turkish government's embracing of Sunnite Muslims through regulatory relief (Korkut, 2016) might explain one interlocutor's statement that Iraqi Sunnis have easier access than Afghans.

\section{Conclusion}

This article shows that the healthcare system in Turkey can be categorised as a system of stratified membership beyond variations in the dimension of legal status. We identified different groups of refugees with entitlements to varying social rights. Beyond the two-track system for refugees in Turkey, with Syrians under temporary protection and non-Syrians as international protection applicants, there are also considerable differences between ethnicities applying for the status of international protection. The two largest refugee groups in Turkey after Syrians - Iraqi Turkmen and Afghans - exemplify considerable variation between two groups of international protection applicants. Next to ethnic categories of origin, factors such as gender, culture, language skills and the individual economic situation play crucial roles. In particular, the last line of division regarding the economic situation blurs the separation between citizens and refugees. Building on an understanding that healthcare policies are political means that can include or exclude immigrants, these insights into varying degrees of access are relevant not only for reflections about social systems but also for discussions on citizenship and immigration. Moreover, this article adds to continuing efforts to break up a Western-centred discussion by shifting the empirical focus to countries which have been less studied in regard to their social policies and immigration regimes, while often bearing the brunt of forced migration. Comparisons with practices in other countries can help to understand the ongoing stratifications of rights.

Here, we take the current two-track system for refugees in Turkey as a starting point. This places a strong emphasis on ethnicity by focusing on Syrians and international protection applicants, and, within that group, on Iraqi Turkmen and Afghans as separate groups. Perspectives which go beyond an ethnic lens (Runfors, 2016) can enrich the proposed stratified membership perspective. Likewise, our proposed distinction of stratified membership as both an empirical fact and a constructed practice deserves 
closer attention. The discursive level which currently constructs 'refugeeness' as Syrian is decisive for people's self-understanding, entitlements, the host population's attitudes and, finally, policy efforts. This article showed that the expansion of social rights to refugees in the case of Turkey has not resulted in standardised implementation mechanisms. Future research needs to further examine the complex interplay of status, rights and identity, to study the implications and to reflect upon the justification and the questionable moral basis for practices of stratified membership.

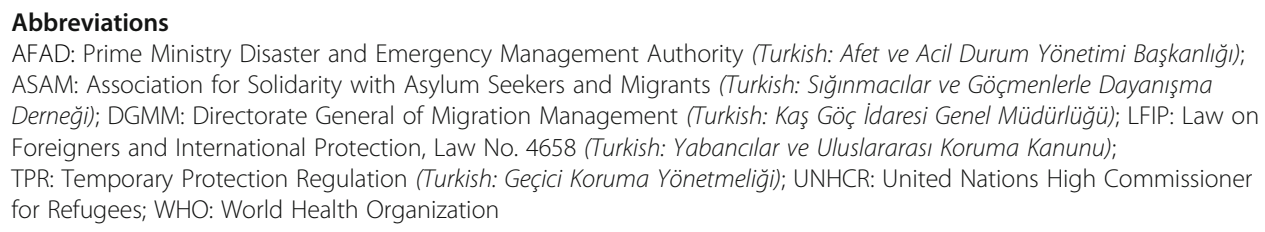

\section{Acknowledgements}

We would like to gratefully acknowledge feedback on the theoretical parts by colleagues from Bilkent University. We extend our gratitude to the refugees, the health personnel, the non-state refugee supporters, the state-affiliated persons and the academics who took the time to speak with us and provide us with valuable insights. We thank the interpreters for their valuable work as well as their indispensable fieldwork assistance in Ankara.

\section{Authors' contributions}

WS and AÖ made substantial contributions to the conception and design of the study. WS performed and analyzed the interviews and drafted the manuscript. WS and AÖ revised it critically for important intellectual content. Both authors read and approved the final manuscript.

\section{Funding}

The authors declare that this project received no funding.

\section{Availability of data and materials}

Not applicable.

\section{Competing interests}

The authors declare that they have no competing interests.

Received: 18 December 2018 Accepted: 6 August 2019

Published online: 23 October 2019

\section{References}

Abbara, A., Coutts, A., Fouad, F. M., Ismail, S. A., Orcutt, M., \& the Syria Public Health Network (2016). Mental health among displaced Syrians: Findings from the Syria public health network. Journal of the Royal Society of Medicine. https://doi.org/1 $0.1177 / 0141076816629765$.

Agartan, T. I. (2012). Marketization and universalism: Crafting the right balance in the Turkish healthcare system. Current Sociology, 60(4), 456-471. https://doi.org/10.1177/0011392112438331.

Aktan, A. O., Pala, K., \& Ilhan, B. (2014). Health-care reform in Turkey: Far from perfect. The Lancet, 383(9911), 25-26. https://doi. org/10.1016/S0140-6736(13)62725-7.

Alemi, Q., Stempel, C., Koga, P., Smith, V., Danis, D., Baek, K., \& Montgomery, S. (2017). Determinants of health care services utilization among first generation afghan migrants in Istanbul. International Journal of Environmental Research and Public Health, 14(2), 201. https://doi.org/10.3390/ijerph14020201.

Alpak, G., Unal, A., Bulbul, F., Sagaltici, E., Bez, Y., Altindag, A., ... Savas, H. A. (2015). Post-traumatic stress disorder among Syrian refugees in Turkey: A cross-sectional study. International Journal of Psychiatry in Clinical Practice, 19(1), 45-50. https://doi.org/10.3109/13651501.2014.961930.

Ataç, I., \& Rosenberger, S. (Eds.) (2013). Politik der Inklusion und Exklusion [Politics of Inclusion and Exclusion]. Göttingen: V\&R Unipress (Vienna University Press).

Atun, R. (2015). Transforming Turkey's health system — Lessons for universal coverage. New England Journal of Medicine, 373(14), 1285-1289. https://doi.org/10.1056/NEJMp1410433.

Atun, R., Aydın, S., Chakraborty, S., Sümer, S., Aran, M., Gürol, I., ... Akdağ, R. (2013). Universal health coverage in Turkey: Enhancement of equity. The Lancet, 382(9886), 65-99. https://doi.org/10.1016/S0140-6736(13)61051-X.

Baban, F., Ilcan, S., \& Rygiel, K. (2017). Syrian refugees in Turkey: Pathways to precarity, differential inclusion, and negotiated citizenship rights. Journal of Ethnic and Migration Studies, 43(1), 41-57. https://doi.org/10.1080/1369183X.2016.1192996.

Baldi, G., \& Goodman, S. W. (2015). Migrants into members: Social rights, civic requirements, and citizenship in Western Europe. West European Politics, 38(6), 1152-1173. https://doi.org/10.1080/01402382.2015.1041237.

Bilecen, B., \& Yurtseven, D. (2018). Temporarily protected Syrians' access to the healthcare system in Turkey: Changing policies and remaining challenges. Migration Letters, 15(1), 113-124. https://doi.org/10.33182/ml.v15i1.344.

Bommes, M., \& Geddes, A. (2000). Immigration and welfare challenging the borders of the welfare state. London; New York: Routledge

Brinkmann, S. (2013). Qualitative interviewing. Oxford: Oxford University Press. 
Bugra, A., \& Candas, A. (2011). Change and continuity under an eclectic social security regime: The case of Turkey. Middle Eastern Studies, 47(3), 515-528. https://doi.org/10.1080/00263206.2011.565145.

Castles, S., \& Schierup, C.-U. (2010). Migration and ethnic Minorites. In F. G. Castles, S. Leibfried, J. Lewis, H. Obinger, \& C. Pierson (Eds.), The Oxford handbook of the welfare state. Oxford: Oxford University Press.

Crawley, H., \& Skleparis, D. (2018). Refugees, migrants, neither, both: Categorical fetishism and the politics of bounding in Europe's 'migration crisis'. Journal of Ethnic and Migration Studies, 44(1), 48-64. https://doi.org/10.1080/1369183X.2017.1348224.

Directorate General of Migration Management. (2019). Statistics. Temporary Protection. Retrieved from https:/en.goc.gov.tr/ temporary-protection27.

Ekmekci, P. E. (2016). Syrian refugees, health and migration legislation in Turkey. Journal of Immigrant and Minority Health, 19(6), 1434-1441. https://doi.org/10.1007/s10903-016-0405-3.

Ergun, A., \& Erdemir, A. (2010). Negotiating Insider and Outsider Identities in the Field: "Insider" in a Foreign Land; "Outsider" in One's Own Land. Field Methods, 22(1), 16-38. https://doi.org/10.1177/1525822X09349919.

Gale, N. K., Heath, G., Cameron, E., Rashid, S., \& Redwood, S. (2013). Using the framework method for the analysis of qualitative data in multi-disciplinary health research. BMC Medical Research Methodology, 13(1), 117. https://doi.org/10.11 86/1471-2288-13-117.

Guiraudon, V. (2000). The Marshallian triptych reordered: The role of courts and bureaucracies in furthering migrants' social rights. In M. Bommes, \& A. Geddes (Eds.), Immigration and welfare. Challenging the borders of the welfare state, (pp. 71-88). London; New York: Routledge.

Ikizoglu Erensu, A. (2016). Notes from a refugee protest: Ambivalences of resisting and desiring citizenship. Citizenship Studies, 20(5), 664-677. https://doi.org/10.1080/13621025.2016.1182677.

Isin, E. F., \& Nielsen, G. M. (Eds.) (2008). Acts of citizenship. London; New York: Zed Books Ltd.; Distributed in the USA by Palgrave Macmillan.

Joppke, C. (2007). Transformation of citizenship: Status, rights, identity. Citizenship Studies, 11(1), 37-48. https://doi.org/10.1 080/13621020601099831.

Kirisci, K. (2014). Syrian refugees and Turkey's challenges: Going beyond hospitality. Washington, D.C: Brookings Institution. Retrieved from https://www.brookings.edu/research/syrian-refugees-and-turkeys-challengesgoing-beyond-hospitality/

Korkut, U. (2016). Pragmatism, moral responsibility or policy change: The Syrian refugee crisis and selective humanitarianism in the Turkish refugee regime. Comparative Migration Studies, 4(2). https://doi.org/10.1186/s40878-015-0020-9.

Law on Foreigners and International Protection. (2013). Law No. 6458, 5(53). Retrieved from https://en.goc.gov.tr/kurumlar/en. goc/Ingilizce-kanun/Law-on-Foreigners-and-International-Protection.pdf.

Mardin, F. D. (2017). Right to health and access to health services for Syrian Refugees in Turkey. Istanbul: Koc University.

Marshall, T. H. (1950). Citizenship and social class and other essays. Cambridge: University Press.

Morris, L. (2002). Managing migration: Civic stratification and migrants' rights. London; New York: Routledge

Olafsdottir, S., \& Bakhtiari, E. (2015). Citizenship and healthcare policy. In E. Kuhlmann, R. H. Blank, I. L. Bourgeault, \& C. Wendt (Eds.), The Palgrave international handbook of healthcare policy and governance, (pp. 561-577). Basingstoke; New York: Palgrave Macmillan.

Öner, N. A. S., \& Genc, D. (2015). Vulnerability leading to mobility: Syrians' exodus from Turkey. Migration Letters, 12(3), 251-262.

Ozcurumez, S., \& Yildırım, D. (2017). Syrians under temporary protection, health services and NGOs in Turkey: The Association for Solidarity with Asylum Seekers and Migrants and the Turkish Medical Association. In G. L. Scott, M. Wismar, G. Pastorino \& M. Kosinska (Eds.), Civil society and health: Contributions and potential (pp. 105-122). Copenhagen: European Observatory on Health Systems and Policies.

Paçacı Elitok, S., \& Straubhaar, T. (Eds.) (2012). Turkey, migration and the EU: Potentials, challenges and opportunities. Hamburg: Hamburg Univ. Press.

Parkinson, S. E., \& Behrouzan, O. (2015). Negotiating health and life: Syrian refugees and the politics of access in Lebanon. Social Science \& Medicine, 146, 324-331. https://doi.org/10.1016/j.socscimed.2015.10.008.

Pfortmueller, C. A., Schwetlick, M., Mueller, T., Lehmann, B., \& Exadaktylos, A. K. (2016). Adult asylum seekers from the Middle East including Syria in Central Europe: What are their health care problems? PLoS One, 11(2), e0148196. https://doi.org/1 0.1371/journal.pone.0148196.

Pope, C. (2000). Qualitative research in health care: Analysing qualitative data. BMJ, 320(7227), 114-116. https://doi.org/1 0.1136/bmj.320.7227.114.

Republic of Turkey Ministry of Health. (2016). Health statistic yearbook 2015. Retrieved from https://dosyamerkez.saglik.gov.tr/ Eklenti/6118,healthstatisticsyearbook2015pdf.pdf?0.

Ritchie, J., Spencer, L., \& O'Connor, W. (2003). Carrying out qualitative analysis. In J. Ritchie, \& J. Lewis (Eds.), Qualitative research practice, (pp. 219-262). London: SAGE.

Runfors, A. (2016). What an ethnic lens can conceal: The emergence of a shared racialised identity position among young descendants of migrants in Sweden. Journal of Ethnic and Migration Studies, 42(11), 1846-1863. https://doi.org/10.1 080/1369183X.2016.1153414

Ryan, L., Kofman, E., \& Aaron, P. (2011). Insiders and outsiders: Working with peer researchers in researching Muslim communities. International Journal of Social Research Methodology, 14(1), 49-60. https://doi.org/10.1080/13645579.2010.481835.

Sainsbury, D. (2012). Welfare states and immigrant rights: The politics of inclusion and exclusion (1st. ed.). Oxford: Oxford University Press.

Sargent, C., \& Larchanché, S. (2011). Transnational migration and global health: The production and management of risk, illness, and access to care. Annual Review of Anthropology, 40(1), 345-361. https://doi.org/10.1146/annurev-anthro-0813 09-145811.

Shinozaki, K. (2012). Transnational dynamics in researching migrants: self-reflexivity and boundary-drawing in fieldwork. Ethnic and Racial Studies 35(10), 1810-1827. https://doi.org/10.1080/01419870.2012.659275.

Soykan, C. (2017). Access to international protection - Border issues in Turkey. In M. O'Sullivan, \& D. Stevens (Eds.), States, the law and access to refugee protection: Fortresses and fairness. Oxford; Portland: Hart Publishing.

Temporary Protection Regulation. (2014). Retrieved from https://en.goc.gov.tr/kurumlar/goc.gov.tr/files/temptemp.pdf.

United Nations High Commissioner for Refugees. (2016a). UNHCR Turkey's monthly statistics. Retrieved from https://www. unhcr.org/tr/en/current-statistics. 
United Nations High Commissioner for Refugees. (2016b). Syria regional refugee response. Retrieved from http://data.unhcr. org/syrianrefugees/country.php?id=224.

United Nations High Commissioner for Refugees. (2019). Registration and RSD with UNHCR. Retrieved from https://help.unhcr. org/turkey/information-for-non-syrians/registration-rsd-with-unhcr/.

United Nations Development Group. (2015). 3 RP Regional Refugee \& Resilience Plan 2015-16 Turkey. In responce to the Syria crisis. Retrieved from https://docs.unocha.org/sites/dms/Syria/3RP-Report-Turkey.pdf.

United Nations Development Group. (2018). 3 RP Regional Refugee \& Resilience Plan 2018-2019. In response to the Syria crisis. Regional Strategic Overview. Retrieved from https://reliefweb.int/sites/reliefweb.int/files/resources/3RP-RegionalStrategic-Overview-2018-19.pdf.

Willen, S. S. (2012). How is health-related "deservingness" reckoned? Perspectives from unauthorized im/migrants in Tel Aviv. Social Science \& Medicine, 74(6), 812-821. https://doi.org/10.1016/j.socscimed.2011.06.033.

Wimmer, A., \& Glick Schiller, N. (2002). Methodological nationalism and the study of migration. European Journal of Sociology, 43(2), 217-240. https://doi.org/10.1017/S000397560200108X.

\section{Publisher's Note}

Springer Nature remains neutral with regard to jurisdictional claims in published maps and institutional affiliations.

Submit your manuscript to a SpringerOpen ${ }^{\circ}$ journal and benefit from:

- Convenient online submission

- Rigorous peer review

- Open access: articles freely available online

- High visibility within the field

- Retaining the copyright to your article

Submit your next manuscript at $\boldsymbol{\nabla}$ springeropen.com 